\title{
Liquid-Crystalline Dye-Sensitized Solar Cells: Design of Two-Dimensional Molecular Assemblies for Efficient Ion Transport and Thermal Stability
}

Daniel Högberg, ${ }^{\dagger}$ Bartolome Soberats, ${ }^{\dagger}$ Ryo Yatagai, ${ }^{\dagger}$ Satoshi Uchida, ${ }^{\ddagger}$ Masafumi Yoshio, ${ }^{\dagger}$ Lars Kloo, ${ }^{\S}$ Hiroshi Segawa, ${ }^{\perp}$ Takashi Kato ${ }^{\dagger} *$

'Department of Chemistry and Biotechnology, School of Engineering, The University of Tokyo, Hongo, Bunkyo-ku, Tokyo 113-8656, Japan

$\$$ Komaba Organization for Educational Excellence, The University of Tokyo, Komaba, Meguro-ku, Tokyo 153-8902

${ }^{\S}$ Applied Physical Chemistry, KTH Royal Institute of Technology, SE 10044 Stockholm, Sweden

$\perp$ Research Center for Advanced Science and Technology, The University of Tokyo, Komaba, Meguroku, Tokyo 153-8904, Japan

\section{Supporting information}

Table of Contents:

1. Synthetic procedures

2. Liquid-crystalline properties

3. Characterization of DSSC

4. References 


\section{Synthetic procedures}

\section{Synthesis of compound 1}

10-Tosyloxy-2,5,8-trioxadecane (5) was prepared following the previously described method. ${ }^{\mathrm{S} 1}$

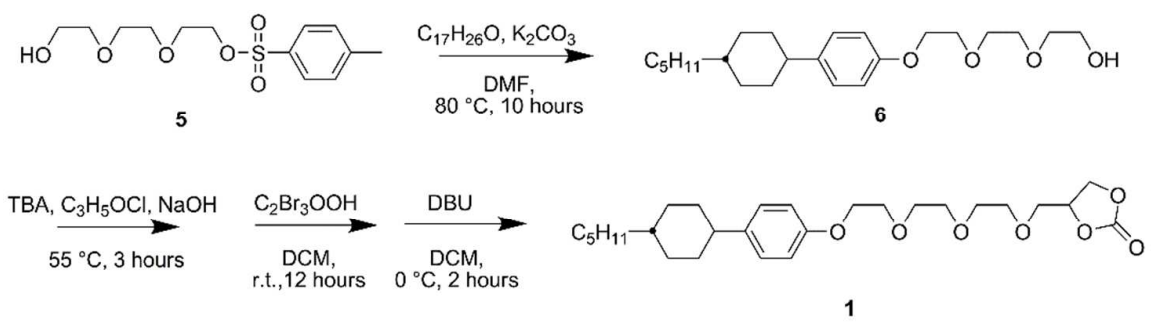

Scheme S1. Reaction scheme for compound 1.

\section{2-(2-\{2-[4-(4-trans-Pentylcyclohexyl)phenoxy]ethoxy\}ethoxy)ethanol (6)}

10-Tosyloxy-2,5,8-trioxadecane (5) (2.2 g, $15.9 \mathrm{mmol})$, potassium carbonate $(2.10 \mathrm{~g}, 15.2$ $\mathrm{mmol})$, and $\mathrm{C}_{17} \mathrm{H}_{26} \mathrm{O}(0.83 \mathrm{~g}, 12.2 \mathrm{mmol})$ was mixed in DMF $(20 \mathrm{ml})$. The reaction mixture was stirred and allowed to react at $80{ }^{\circ} \mathrm{C}$ for 10 hours. Solvent was removed from the reaction mixture and the crude product was washed with water and $\mathrm{CHCl}_{3}$. The product was purified by silica gel chromatography (eluent: hexane/ ethyl acetate $=1: 1$ ). Compound $\mathbf{6}$ was obtained as a transparent waxy solid with $54 \%$ yield $(1.5 \mathrm{~g}, 3.2 \mathrm{mmol})$.

${ }^{1} \mathrm{H}$ NMR (400 MHz, $\left.\mathrm{CDCl}_{3}\right): \delta=7.11(\mathrm{~d}, J=8.8 \mathrm{~Hz}, 2 \mathrm{H}), 6.84(\mathrm{~d}, J=8.8 \mathrm{~Hz}, 2 \mathrm{H}), 4.10(\mathrm{t}, J=$ $4.8 \mathrm{~Hz}, 2 \mathrm{H}), 3.84(\mathrm{t}, J=4.8 \mathrm{~Hz}, 2 \mathrm{H}), 3.74-3.69(\mathrm{~m}, 6 \mathrm{H}), 3.61(\mathrm{t}, J=4.8 \mathrm{~Hz}, 2 \mathrm{H}), 2.39(\mathrm{~m}, 1 \mathrm{H}), 1.85$ $(\mathrm{d}, J=10.0 \mathrm{~Hz}, 4 \mathrm{H}), 1.44-1.20(\mathrm{~m}, 11 \mathrm{H}), 1.01(\mathrm{~m}, 2 \mathrm{H}), 0.89(\mathrm{t}, J=7.2 \mathrm{~Hz}, 3 \mathrm{H}) .{ }^{13} \mathrm{C} \mathrm{NMR}(100 \mathrm{MHz}$, $\left.\mathrm{CDCl}_{3}\right): \delta=156.67,140.40,127.60,114.31,72.48,70.75,70.31,69.76,67.29,61.71,43.68,37.35$, $37.25,34.51,33.60,32.18,26.63,22.69$, 14.10. IR (KBr): 3041, 2954, 2916, 2847, 1804, 1610, 1580, 1514, 1471, 1391, 1283, 1248, 1181, 1155, 1111, 1075, 1056, 1021, 829, 775, 737, 625, $545 \mathrm{~cm}^{-1}$. MS (MALDI-TOF): calcd. for $[\mathrm{M}+\mathrm{Na}]^{+}, 401.270$; found, 401.204. Elemental analysis: calcd. (\%) for $\mathrm{C}_{23} \mathrm{H}_{38} \mathrm{O}_{4}$ : C, 72.98; H, 10.12. Found: C, 72.70; H, 10.36 .

\section{2-[2-(2-\{2-[4-(4-trans-Pentylcyclohexyl)phenoxy]ethoxy\}ethoxy)ethoxy]ethyl carbonate (1)}

Compound $6(0.50 \mathrm{~g}, 1.3 \mathrm{mmol})$ was dissolved in $2 \mathrm{ml}$ of 2-(chloromethyl)oxirane and added at $0 \quad{ }^{\circ} \mathrm{C}$ to $1 \mathrm{ml}$ of 2-(chloromethyl)oxirane, sodium hydroxide $(1.38 \mathrm{~g}, 34.4 \mathrm{mmol})$ and tetrabutylammonium hydrogensulfate $(0.06 \mathrm{~g}, 0.3 \mathrm{mmol})$. The mixture was let react at $55{ }^{\circ} \mathrm{C}$ for 3 hours. The crude product was extracted with ethylacetate and washed with brine. The solvent was removed and the crude product was obtained as a yellow oil. The oil was dissolved in $20 \mathrm{ml}$ of dichloromethane and tribromomethaneacetic acid $(1.9 \mathrm{~g}, 6.6 \mathrm{mmol})$ was added. The reaction was allowed to stir for 12 hours and then DBU $(2.2 \mathrm{~g}, 14.6 \mathrm{~mm})$ was added at $0^{\circ} \mathrm{C}$ and stirred for additional 2 hours. The reaction was quenched with saturated bicarbonate solution and washed with water and chloroform. The product was purified by silica gel chromatography (eluent: chloroform/ ethyl acetate $=4: 1)$. Compound 1 was obtained as a transparent waxy solid with $62 \%$ yield $(0.39 \mathrm{~g}, 0.8$ mmol). 
${ }^{1} \mathrm{H}$ NMR $\left(400 \mathrm{MHz}, \mathrm{CDCl}_{3}\right): \delta=7.10(\mathrm{~d}, J=8.8 \mathrm{~Hz}, 2 \mathrm{H}), 6.83(\mathrm{~d}, J=8.8 \mathrm{~Hz}, 2 \mathrm{H}), 4.74(\mathrm{~m}$, $1 \mathrm{H}), 4.42(\mathrm{~m}, 2 \mathrm{H}), 4.10(\mathrm{t}, J=4.8 \mathrm{~Hz}, 2 \mathrm{H}), 3.83(\mathrm{t}, J=4.8 \mathrm{~Hz}, 2 \mathrm{H}), 3.70-3.65(\mathrm{~m}, 10 \mathrm{H}), 2.42-2.36(\mathrm{~m}$, $1 \mathrm{H}), 1.85(\mathrm{~d}, J=10.4 \mathrm{~Hz}, 4 \mathrm{H}), 1.44-1.20(\mathrm{~m}, 11 \mathrm{H}), 1.07-0.97(\mathrm{~m}, 2 \mathrm{H}), 0.89(\mathrm{t}, J=7.2 \mathrm{~Hz}, 3 \mathrm{H}) .{ }^{13} \mathrm{C}$ NMR (100 MHz, $\left.\mathrm{CDCl}_{3}\right): \delta=156.81,154.94,140.44,127.64,114.34,77.34,77.03,76.71,75.02$, $71.32,70.78,70.70,70.66,70.22,69.80,67.44,66.28,43.73,37.39,37.31,34.58,33.64,32.22,26.66$, 22.72, 14.13. MS (MALDI-TOF): calcd. for $[\mathrm{M}+\mathrm{Na}]^{+}$, 501.283; found, 500.739. Elemental analysis: calcd. (\%) for $\mathrm{C}_{27} \mathrm{H}_{42} \mathrm{O}_{7}$ : C, 67.76; $\mathrm{H}, 8.84$. Found: $\mathrm{C}, 67.38 ; \mathrm{H}, 8.96$.

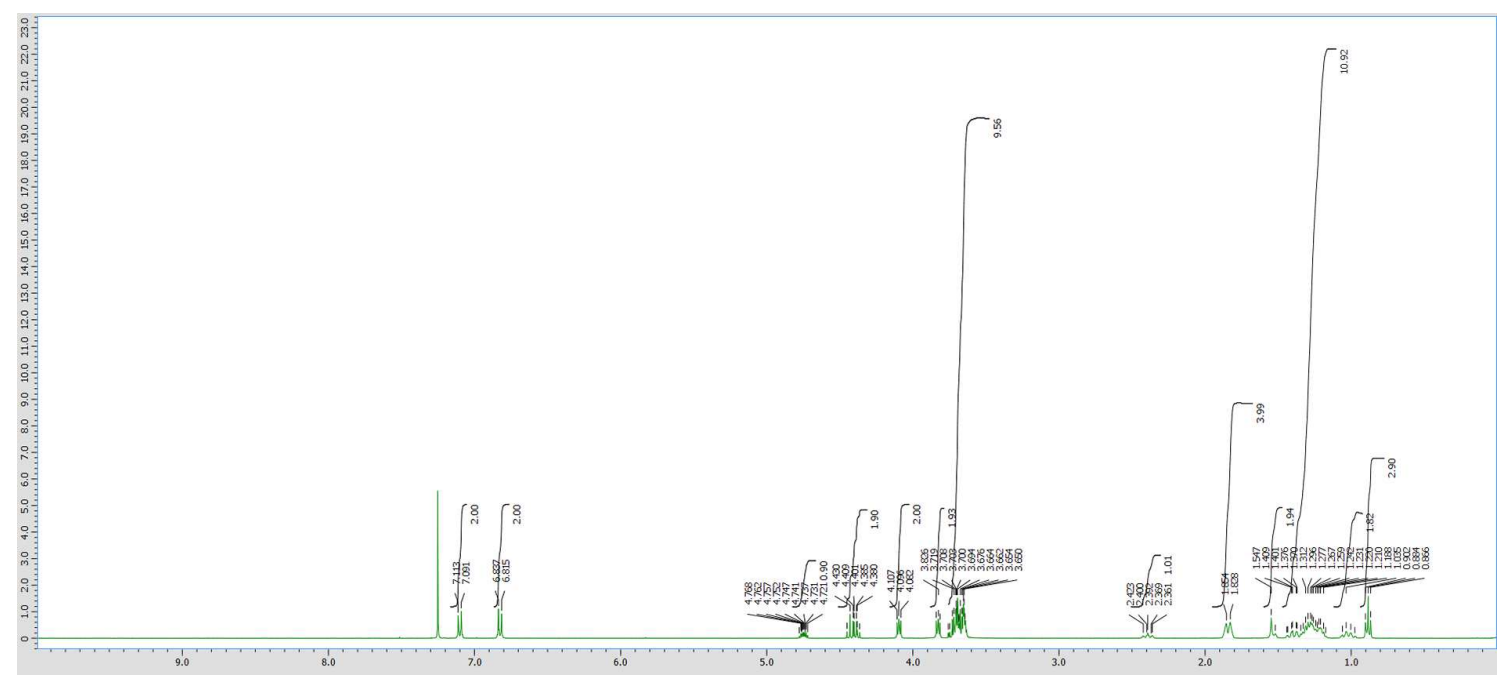

Figure S1. ${ }^{1} \mathrm{H}-\mathrm{NMR}$ spectrum of compound $\mathbf{1 .}$

\section{Synthesis of compound 2}

2-[2-(2-\{2-[4-(4-trans-Pentylcyclohexyl)phenoxy]ethoxy\}ethoxy)ethoxy]ethanol tosylate (7) was prepared following the previously described method. ${ }^{\text {S2 }}$
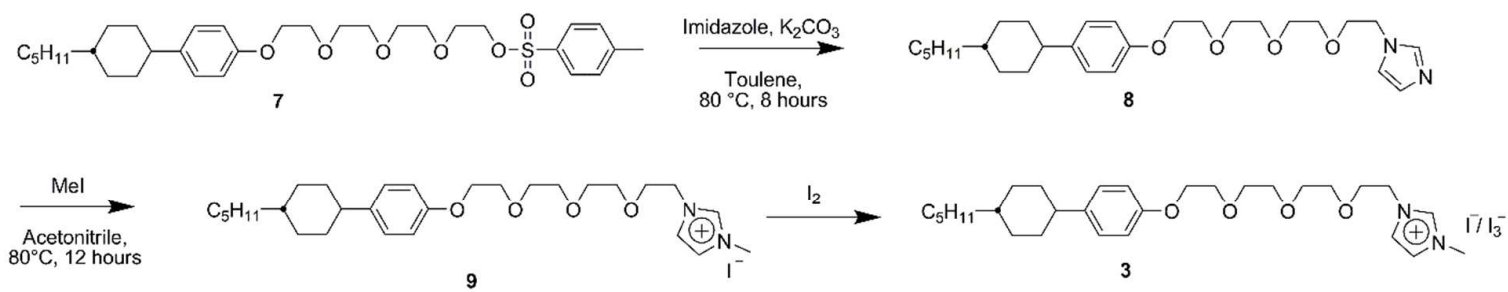

Scheme S2. Reaction scheme for compound 2.

\section{2-[2-(2-\{2-[4-(4-trans-Pentylcyclohexyl)phenoxy]ethoxy\}ethoxy)ethoxy]ethyl imidazole (8)}

Compound 7 (6.00 g, $10.1 \mathrm{mmol})$, potassium carbonate $(2.10 \mathrm{~g}, 15.2 \mathrm{mmol})$ and, imidazole $(0.83 \mathrm{~g}, 12.2 \mathrm{mmol})$ were mixed in toluene $(150 \mathrm{ml})$ and stirred at $80{ }^{\circ} \mathrm{C}$ for 10 hours. Solvent was removed from the reaction mixture and the crude product was extracted with a mixture of water and $\mathrm{CHCl}_{3}$. The product was purified by silica gel chromatography (eluent: chloroform / methanol =9:1). Compound $\mathbf{8}$ was obtained as a transparent waxy solid with $31 \%$ yield $(1.5 \mathrm{~g}, 3.18 \mathrm{mmol})$. 
${ }^{1} \mathrm{H}$ NMR $\left(400 \mathrm{MHz}, \mathrm{CDCl}_{3}\right): \delta=7.51(\mathrm{~s}, 1 \mathrm{H}), 7.10(\mathrm{~d}, J=8.8 \mathrm{~Hz}, 2 \mathrm{H}), 7.05(\mathrm{~s}, 1 \mathrm{H}), 6.99$ (s, $1 \mathrm{H}), 6.83(\mathrm{~d}, J=8.8 \mathrm{~Hz}, 2 \mathrm{H}), 4.11(\mathrm{~m}, 4 \mathrm{H}), 3.83(\mathrm{t}, J=4.8 \mathrm{~Hz}, 2 \mathrm{H}), 3.76-3.69(\mathrm{~m}, 4 \mathrm{H}), 3.68-3.59(\mathrm{~m}$, $6 \mathrm{H}), 2.49-2.35(\mathrm{t}, 1 \mathrm{H}), 1.85(\mathrm{~d}, J=11.2 \mathrm{~Hz}, 4 \mathrm{H}), 1.44-1.20(\mathrm{~m}, 11 \mathrm{H}), 1.06(\mathrm{~m}, 2 \mathrm{H}), 0.89(\mathrm{t}, J=6.8 \mathrm{~Hz}$, $3 \mathrm{H}) .{ }^{13} \mathrm{C} \mathrm{NMR}\left(100 \mathrm{MHz}, \mathrm{CDCl}_{3}\right): \delta=156.92,140.47,137.60,129.25,127.70,119.51,114.47,77.42$, $77.30,77.10,76.78,70.89,70.78,70.74,70.71,70.62,69.90,67.51,47.14,43.81,37.47,37.40,34.66$, 33.73, 32.30, 26.74, 22.79, 14.19. MS (MALDI-TOF): calcd. for $[\mathrm{M}+\mathrm{H}]^{+}, 473.333$; found,.473.251 Elemental analysis: calcd. (\%) for $\mathrm{C}_{28} \mathrm{H}_{46} \mathrm{~N}_{2} \mathrm{O}_{4}$ : C, 71.15; H, 9.38; N, 5.93. Found: C, 70.93; H, 9.78; $\mathrm{N}, 6.30$.

\section{2-[2-(2-\{2-[4-(4-trans-Pentylcyclohexyl)phenoxy]ethoxy\}ethoxy)ethoxy]ethyl imidazolium iodide (9)}

Compound $8(1.50 \mathrm{~g}, 3.18 \mathrm{mmol})$ was dissolved in acetonitrile and methyl iodide $(0.82 \mathrm{ml}$, $12.70 \mathrm{mmol}$ ) was added drop wise under stirring. The mixture was allowed to react for 8 hours at 80 ${ }^{\circ} \mathrm{C}$. Solvent was removed from the reaction mixture and the crude product was washed with water and $\mathrm{CHCl}_{3}$. The product was purified by silica gel chromatography (eluent: chloroform / methanol = 9:1) . Compound 9 was obtained as a pale yellow transparent waxy solid with $72 \%$ yield $(1.40 \mathrm{~g}, 2.28$ mmol).

${ }^{1} \mathrm{H}$ NMR (400 MHz, $\left.\mathrm{CDCl}_{3}\right): \delta=10.05(\mathrm{~s}, 1 \mathrm{H}), 7.69(\mathrm{~s}, 1 \mathrm{H}), 7.10(\mathrm{~d}, J=8.8 \mathrm{~Hz}, 2 \mathrm{H}), 7.05$ (s, $1 \mathrm{H}), 6.78(\mathrm{~d}, J=8.8 \mathrm{~Hz}, 2 \mathrm{H}), 4.52$ (t, $J=4.8 \mathrm{~Hz}, 2 \mathrm{H}), 4.05$ (t, $J=4.8 \mathrm{~Hz}, 12 \mathrm{~Hz}, 2 \mathrm{H}), 3.90-3.55$ (m, $15 \mathrm{H}), 2.39(\mathrm{~m}, 1 \mathrm{H}) 1.82(\mathrm{~d}, J=11.2 \mathrm{~Hz}, 4 \mathrm{H}), 1.43-1.17(\mathrm{~m}, 11 \mathrm{H}), 1.07-0.97(\mathrm{~m}, 2 \mathrm{H}), 0.89$ (t, $J=6.8$ $\mathrm{Hz}, 3 \mathrm{H}) .{ }^{13} \mathrm{C} \mathrm{NMR}\left(100 \mathrm{MHz}, \mathrm{CDCl}_{3}\right): \delta=156.43,140.62,136.92,127.72,123.64,122.77,114.11$, $77.32,77.21,77.00,76.78,70.54,70.22,70.11,70.08,69.71,68.62,67.34,49.67,43.57,37.25,37.15$, 36.57, 34.47, 33.47, 32.09, 26.54, 22.60, 14.02. (MALDI-TOF): calcd. for $[\mathrm{M}]^{+}, 487.353$; found, 487.154. Elemental analysis: calcd. (\%) for $\mathrm{C}_{29} \mathrm{H}_{47} \mathrm{IN}_{2} \mathrm{O}_{4}$ : C, 56.67; H, 7.71, N, 4.56 Found: C, 56.40; $\mathrm{H}, 7.78$. N, 4.44.

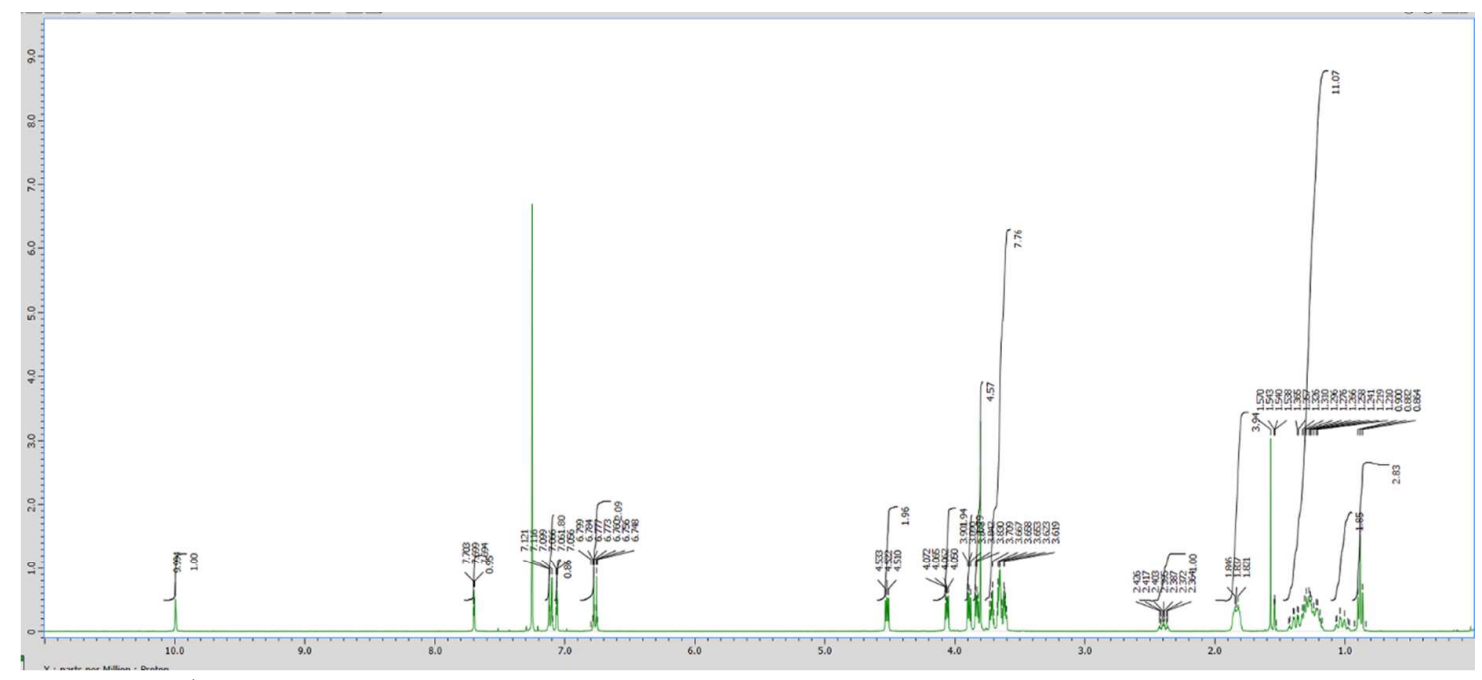

Figure S2. ${ }^{1} \mathrm{H}-\mathrm{NMR}$ spectrum of compound 9. 


\section{Synthesis of compound 4}

4-[4-(4-trans-Pentylcyclohexyl)phenoxy]butyl bromine (10) was prepared following the previously described method. ${ }^{\mathrm{S3}}$

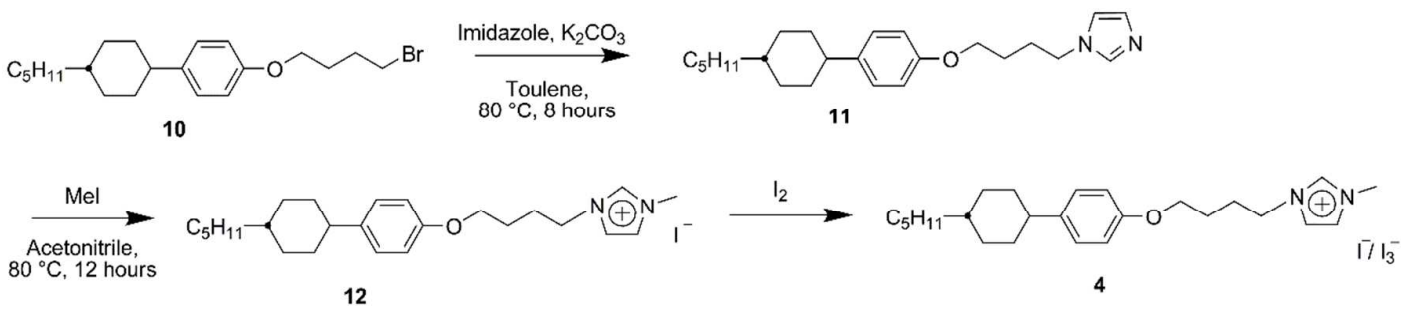

Scheme S3. Reaction scheme for compound 4.

\section{4-[4-(4-trans-Pentylcyclohexyl)phenoxy]buyl imidazole (11)}

Compound 10 (2.1 g, $5.7 \mathrm{mmol})$, potassium carbonate $(0.7 \mathrm{~g}, 5.7 \mathrm{mmol})$ and, imidazole $(0.34 \mathrm{~g}$, $8.6 \mathrm{mmol})$ were mixed in toluene $(150 \mathrm{ml})$. The reaction mixture was stirred and allowed to react at 80 ${ }^{\circ} \mathrm{C}$ for 10 hours. Solvent was removed from the reaction mixture and the crude product was washed with water and $\mathrm{CHCl}_{3}$. The product was purified by silica gel chromatography (eluent: chloroform / methanol = 9:1). Compound 11 was obtained as a transparent waxy solid with $32 \%$ yield $(0.67 \mathrm{~g}, 1.8$ $\mathrm{mmol})$.

${ }^{1} \mathrm{H}$ NMR $\left(400 \mathrm{MHz}, \mathrm{CDCl}_{3}\right): \delta=7.48(\mathrm{~s}, 1 \mathrm{H}), 7.10(\mathrm{~d}, J=8.4 \mathrm{~Hz}, 2 \mathrm{H}), 7.06(\mathrm{~s}, 1 \mathrm{H}), 6.92(\mathrm{~s}$, $1 \mathrm{H}), 6.79(\mathrm{~d}, J=6.8 \mathrm{~Hz}, 2 \mathrm{H}), 4.01(\mathrm{t}, J=7.6 \mathrm{~Hz}, 2 \mathrm{H}), 3.94(\mathrm{t}, J=6 \mathrm{~Hz}, 2 \mathrm{H}), 2.39(\mathrm{tt}, J=12 \mathrm{~Hz}, 1 \mathrm{H})$, $1.95(\mathrm{~m}, 2 \mathrm{H}), 1.85(\mathrm{~d}, J=10.8 \mathrm{~Hz}, 4 \mathrm{H}), 1.75(\mathrm{~m}, 2 \mathrm{H}), 1.44-1.14(\mathrm{~m}, 11 \mathrm{H}), 1.04(\mathrm{~m}, 2 \mathrm{H}), 0.89(\mathrm{t}, J=$ $7.6 \mathrm{~Hz}, 3 \mathrm{H}) .{ }^{13} \mathrm{C}$ NMR $\left(100 \mathrm{MHz}, \mathrm{CDCl}_{3}\right): \delta=156.80,140.41,137.12,129.56,127.70,119.56$, $114.16,77.35,77.23,77.03,76.71,67.04,46.74,43.73,37.39,37.30,34.58,33.63,32.21,26.66$, 26.33, 22.73, 14.13. MS (MALDI-TOF): calcd. for $[\mathrm{M}+\mathrm{H}]^{+}, 369.28$; found,.369.36. Elemental analysis: calcd. (\%) for $\mathrm{C}_{24} \mathrm{H}_{36} \mathrm{~N}_{2} \mathrm{O}: \mathrm{C}, 78.21 ; \mathrm{H}, 9.85 ; \mathrm{N}, 7.60$. Found: C, 78.36; H, 10.10; N, 7.55.

\section{4-[4-(4-trans-Pentylcyclohexyl)phenoxy]butyl imidazolium iodide (12)}

Compound 11 (0.19 g, $0.50 \mathrm{mmol})$ was dissolved in acetonitrile and methyl iodide $(0.13 \mathrm{ml}$, $2.10 \mathrm{mmol}$ ) was added drop wise under stirring. The mixture was let react for 8 hours at $80{ }^{\circ} \mathrm{C}$. Solvent was removed from the reaction mixture and the crude product was washed with water and $\mathrm{CHCl}_{3}$. The product was purified by silica gel chromatography (eluent: chloroform / methanol = 9:1) . Compound 12 was obtained as a pale yellow transparent waxy solid with $68.0 \%$ yield $(0.18 \mathrm{~g}, 0.35$ mmol).

${ }^{1} \mathrm{H}$ NMR (400 MHz, $\left.\mathrm{CDCl}_{3}\right): \delta=10.40(\mathrm{~s}, 1 \mathrm{H}), 7.26(\mathrm{~s}, 1 \mathrm{H}), 7.19(\mathrm{~d}, J=8.8 \mathrm{~Hz}, 2 \mathrm{H}), 7.10(\mathrm{~s}$, $1 \mathrm{H}), 6.80(\mathrm{~d}, J=8.8 \mathrm{~Hz}, 2 \mathrm{H}), 4.46(\mathrm{t}, J=4.8 \mathrm{~Hz}, 2 \mathrm{H}), 4.07$ (s, 3H), 4.00 (t, $J=6.2 \mathrm{~Hz}, 2 \mathrm{H}), 2.39$ (tt, $J$ $=12 \mathrm{~Hz}, 1 \mathrm{H}), 2.18(\mathrm{~m}, 2 \mathrm{H}), 1.88(\mathrm{~m}, 6 \mathrm{H}) 1.57-1.17(\mathrm{~m}, 11 \mathrm{H}), 1.07-0.97(\mathrm{~m}, 2 \mathrm{H}), 0.89(\mathrm{t}, J=6.8 \mathrm{~Hz}$, 3H). ${ }^{13} \mathrm{C}$ NMR (100 MHz, $\left.\mathrm{CDCl}_{3}\right): \delta=156.62,140.73,137.69,127.87,123.04,121.93,114.28,77.42$, 77.30, 77.10, 76.78, 67.01, 50.11, 43.81, 37.48, 37.38, 37.08, 34.67, 33.70, 32.30, 27.60, 26.74, 25.93, 22.80, 14.21 (MALDI-TOF): calcd. for $[\mathrm{M}]^{+}, 383.59$; found, 383.39. Elemental analysis: calcd. (\%) for $\mathrm{C}_{25} \mathrm{H}_{39} \mathrm{IN}_{2} \mathrm{O}$ : C, 58.82; H, 7.70, N, 5.49 Found: C, 58.98; H, 7.68. N, 5.45. 


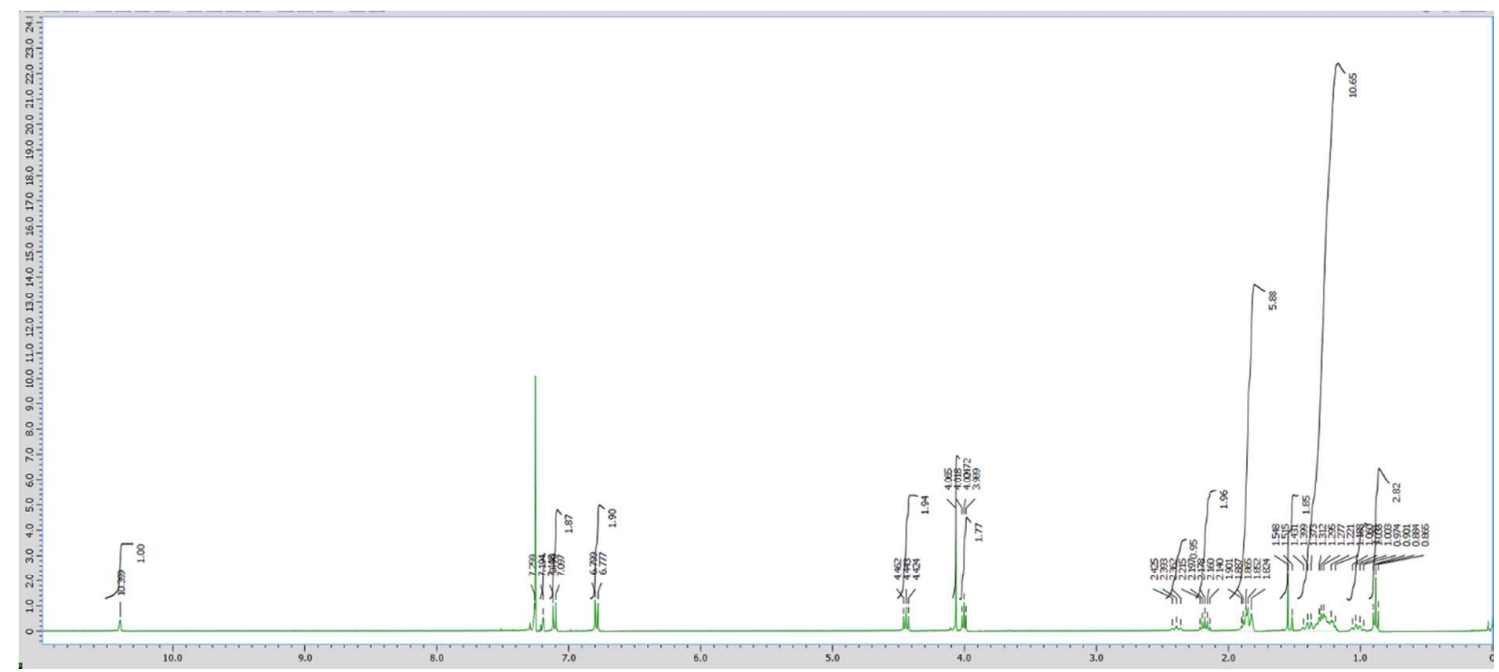

Figure S3. ${ }^{1} \mathrm{H}-\mathrm{NMR}$ spectrum of compound 13.

\section{Preparation of electrolytes}

\section{Electrolyte 1/EMII and 2/EMII}

A stock solution of EMII and $\mathrm{I}_{2}$ in a 5:1 molar ratio was prepared (EMII-I $\left.\mathbf{2}_{\mathbf{2}}\right)$. The appropriate amount of EMII-I $\mathbf{I}_{2}$ was added to weighted samples of $\mathbf{1}$ and $\mathbf{2}$ to obtain the desired ratios between mesogenic compound and ionic liquid. The mixtures were diluted in sufficient amount of acetonitrile to obtain homogenous mixtures. The solvent was then evaporated and the sample was dried under vacuum at $50{ }^{\circ} \mathrm{C}$ for 8 hours.

\section{Electrolyte 3 and 4}

Electrolytes 3 and $\mathbf{4}$ was prepared by addition of $20 \mathrm{~mol} \%$ iodine to compound $\mathbf{9}$ and $\mathbf{1 2}$ respectively, and diluted in sufficient amount of acetonitrile to obtain homogenous mixtures. The solvent was then evaporated and the sample was dried under vacuum at $50{ }^{\circ} \mathrm{C}$ for 8 hours. 


\section{Liquid-crystalline properties}

\section{Compound 1}

Liquid-crystalline (LC) properties of compound $\mathbf{1}$ were studied by differential scanning calorimetry (DSC), X-ray diffraction (XRD) and polarized optical microscopy (POM). The phase transition temperatures were determined as the onset point of the transition peak.

a)

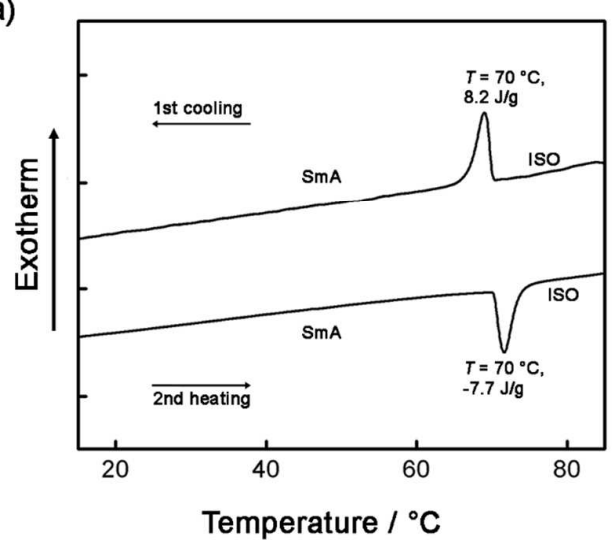

b)

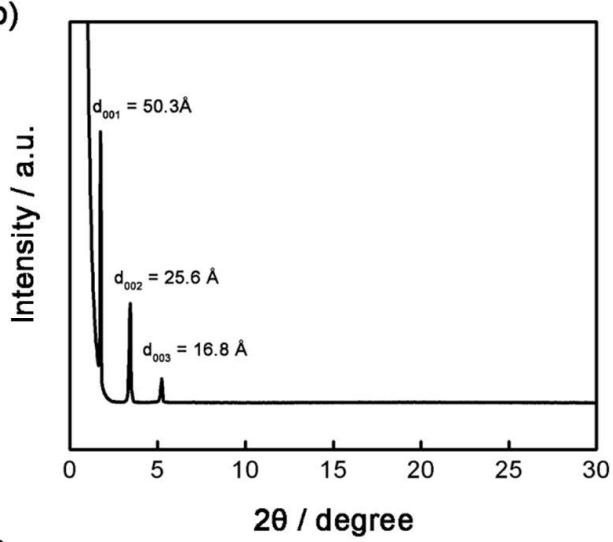

c)

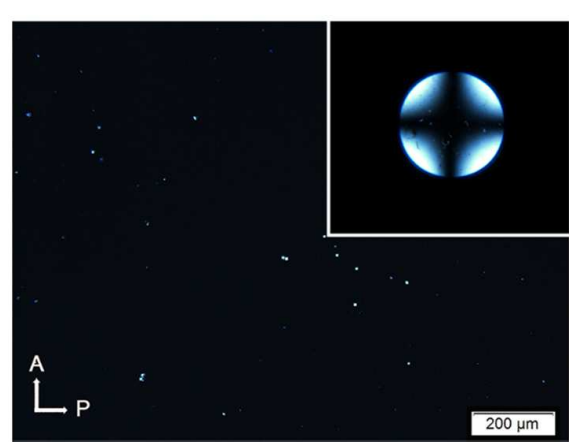

Figure S4. a) DSC thermogram of 1 at a scanning rate of $10 \mathrm{k} \mathrm{min}^{-1}$. The isotropic peak transition temperature was determined to be $72{ }^{\circ} \mathrm{C}$ on heating and $69^{\circ} \mathrm{C}$ on cooling. b) XRD pattern of 1 at 30 ${ }^{\circ} \mathrm{C}$. c) $\mathrm{POM}$ of image 1 at $30^{\circ} \mathrm{C}$ on cooling. The inset shows the conoscopic image. 


\section{Mixture 1/EMII}

LC properties of mixture 1/EMII were studied by DSC, XRD and POM. The phase transition temperatures were determined as the onset point of the transition peak. Water content was estimated to be $\sim 1 \mathrm{wt} \%$ from the thermogravimetric analysis (TGA).

a)

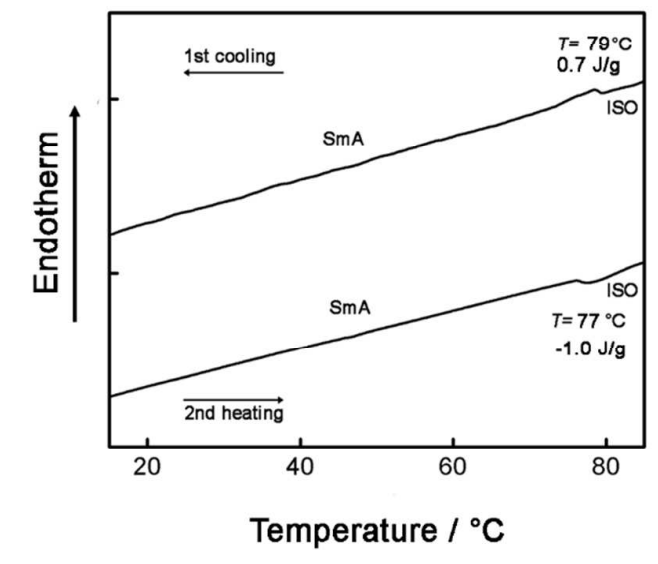

c)

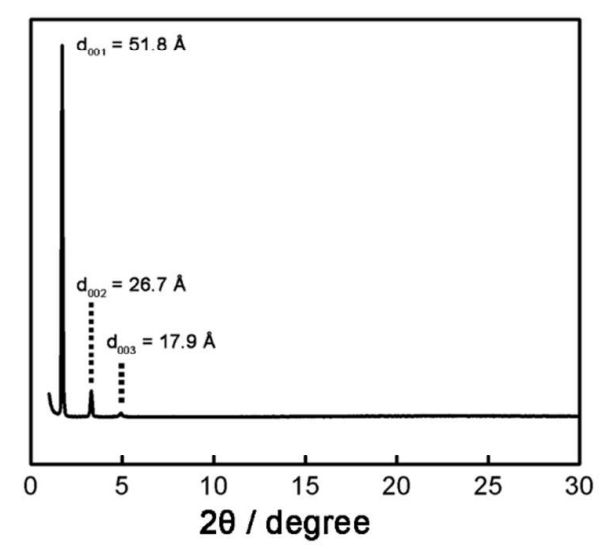

b)

Temperature $/{ }^{\circ} \mathrm{C}$

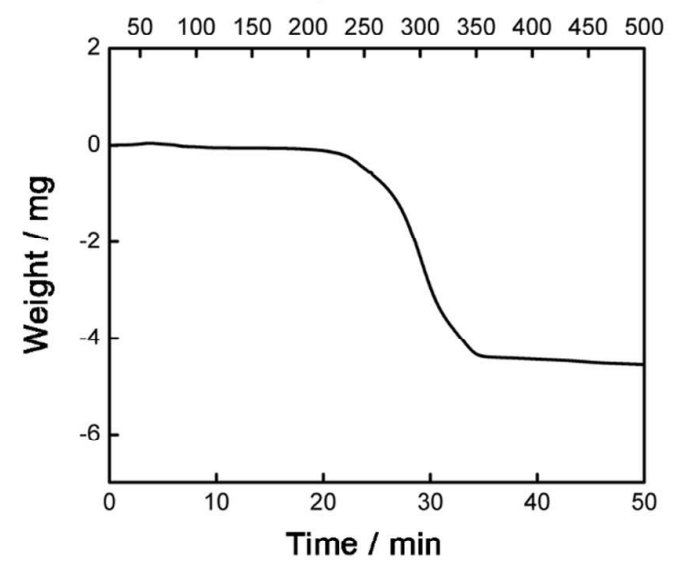

d)

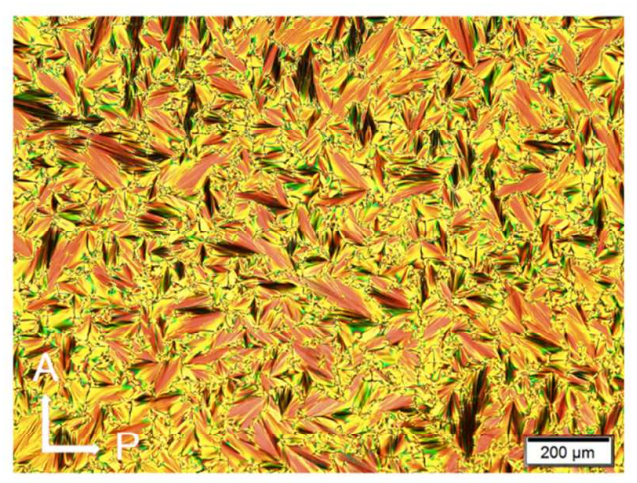

Figure S5. a) DSC thermogram of $\mathbf{1 / E M I I}$ at a scanning rate of $10 \mathrm{k} \mathrm{min}^{-1}$. The peak transition temperature was determined to be $78^{\circ} \mathrm{C}$ on heating and $78^{\circ} \mathrm{C}$ on cooling. b) TGA thermogram of 1/EMII. c) XRD pattern of 1/EMII at $30^{\circ} \mathrm{C}$. d) POM of image $1 / \mathbf{E M I I}$ at $30^{\circ} \mathrm{C}$ on cooling. 


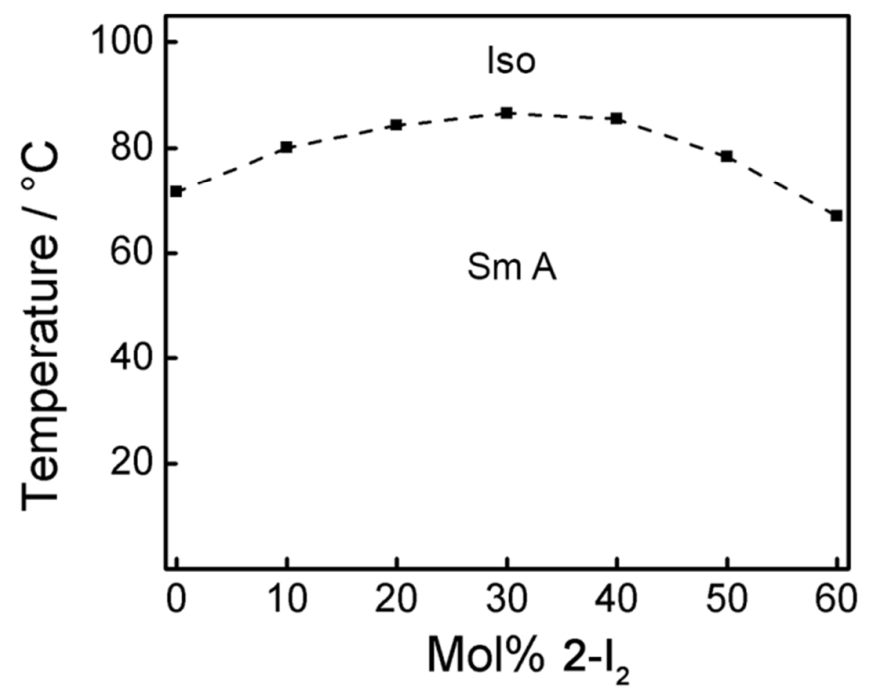

Figure S6. Phase diagrams of mixtures containing 1/EMII and EMII.

Table S1. Phase transition of mixtures between 1 and 0-90 mol\% of EMII.

\begin{tabular}{cc}
\hline mol \% of EMII & Phase transition temperatures $^{a}$ \\
\hline 0 & SmA 72 Iso \\
10 & SmA 80 Iso \\
20 & SmA 84 Iso \\
30 & SmA 87 Iso \\
40 & SmA 85 Iso \\
50 & SmA 78 Iso \\
60 & SmA 67 Iso \\
70 & Phase Separation \\
80 & Phase Separation \\
90 & Phase Separation \\
\hline
\end{tabular}

${ }^{a}$ Phase transition temperatures $\left({ }^{\circ} \mathrm{C}\right)$ of $\mathbf{1}$ and EMII mixtures obtained from DSC measurements between -20 and $100{ }^{\circ} \mathrm{C}$. The scan rate is $10{ }^{\circ} \mathrm{C} \mathrm{min}^{-1}$. SmA: smectic A; Iso: isotropic. 


\section{Mixture 2/EMII}

LC properties of mixture 2/EMII were studied by DSC, XRD and POM. The phase transition temperatures were determined as the onset point of the transition peaks. XRD measurement and POM image was taken on cooling.

a)

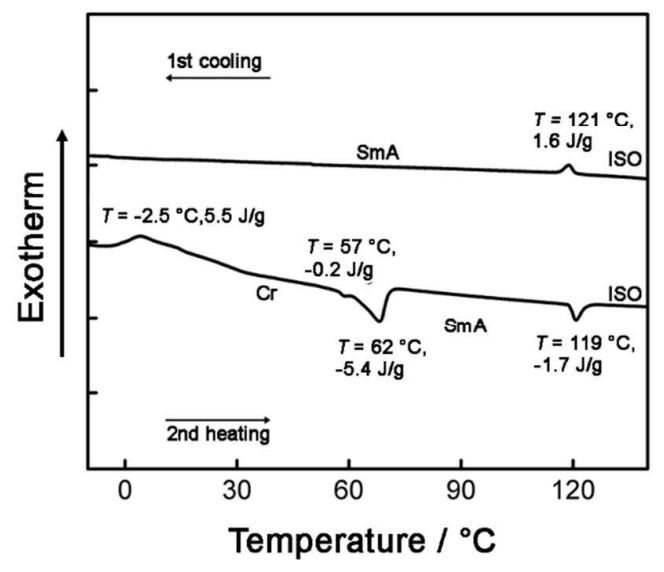

b)

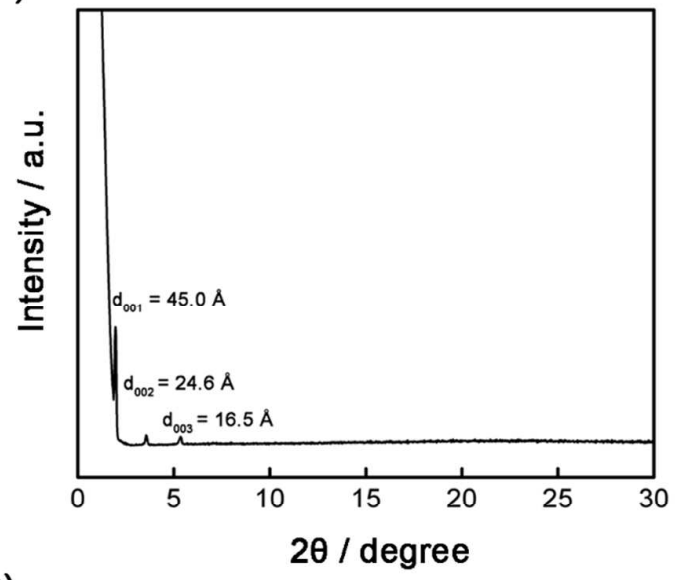

c)

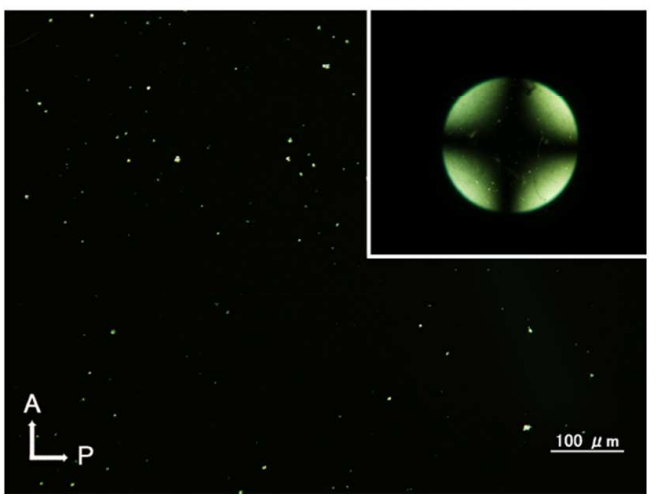

Figure S7. a) DSC thermogram of 2/EMII at a scanning rate of $10 \mathrm{k} \mathrm{min}^{-1}$. The peak transition temperature was determined to be $121^{\circ} \mathrm{C}$ on heating and $119^{\circ} \mathrm{C}$ on cooling. b) XRD pattern of 2/EMII at $30^{\circ} \mathrm{C}$. c) POM of image $2 / \mathbf{E M I I}$ at $30^{\circ} \mathrm{C}$ on cooling. The inset shows the conoscopic image. 


\section{Compound 9}

LC properties of compound 9 were studied by DSC and POM. The phase transition temperatures were determined as the onset point of the transition peak.

a)

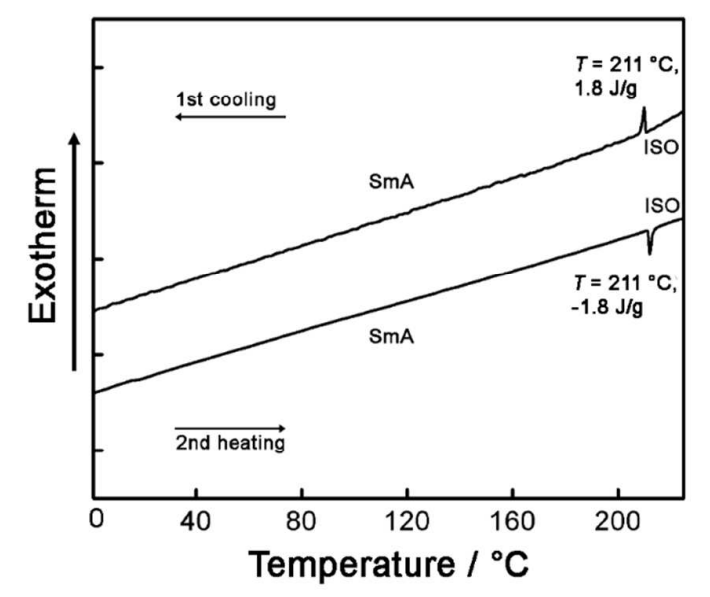

b)

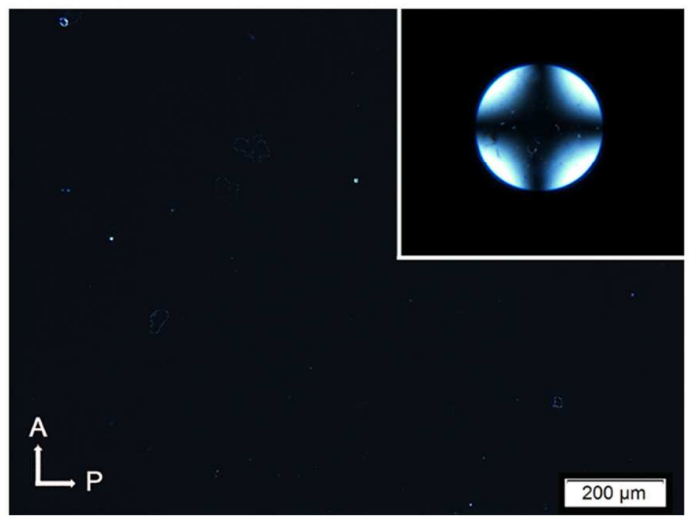

Figure S8. a) DSC thermogram of 9 at a scanning rate of $10 \mathrm{k} \mathrm{min}^{-1}$. The isotropic peak transition temperature was determined to be $212^{\circ} \mathrm{C}$ on heating and $210^{\circ} \mathrm{C}$ on cooling. b) POM of image 9 at 30 ${ }^{\circ} \mathrm{C}$ on cooling. The inset shows the conoscopic image. 


\section{Compound 3}

LC properties of compound 3 were studied by DSC, XRD and POM. The phase transition temperatures were determined as the onset point of the transition peak. Water content was estimated to be $\sim 5 \mathrm{wt} \%$ from the TGA.

a)

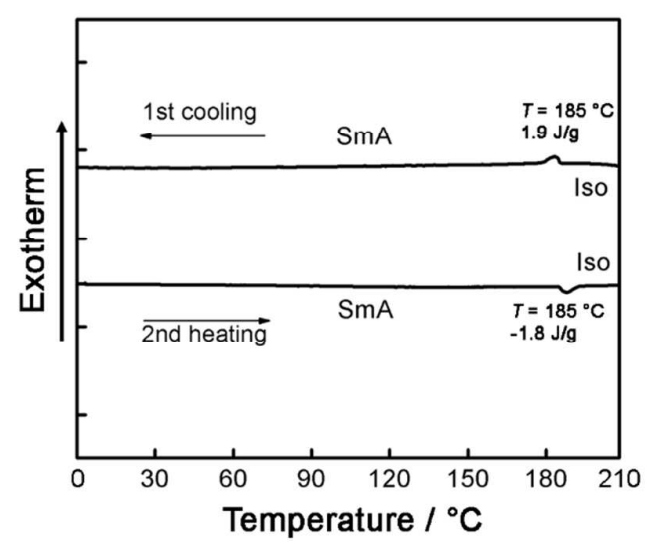

c)

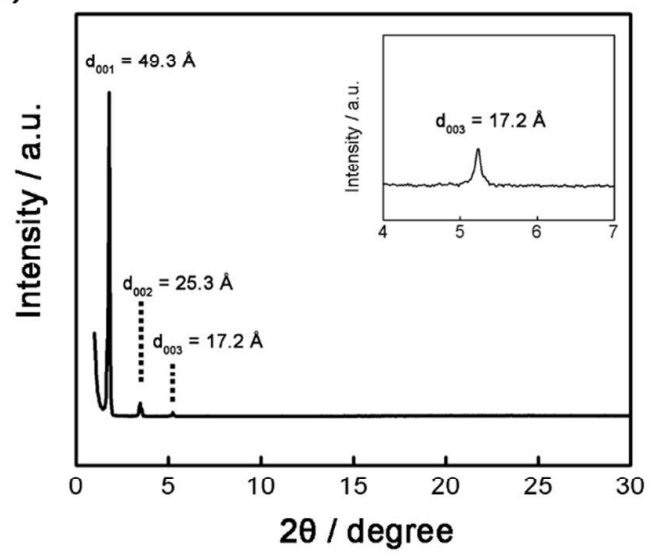

b)

Temperature $1^{\circ} \mathrm{C}$

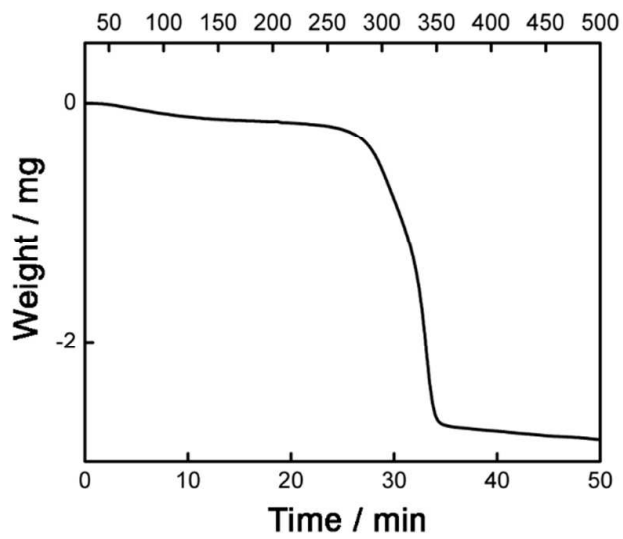

d)

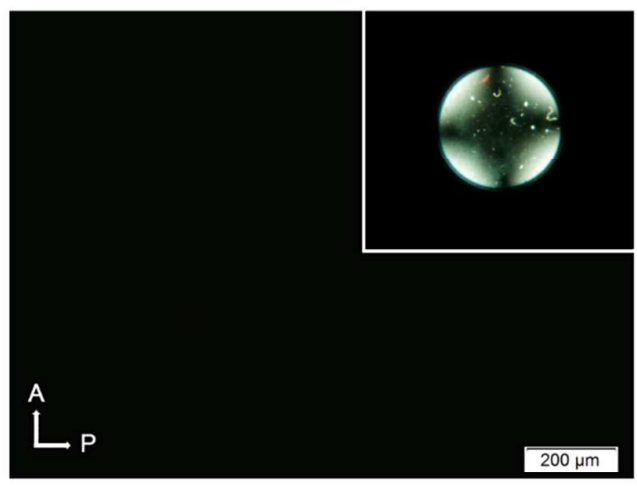

Figure S9. a) DSC thermogram of 3 at a scanning rate of $10 \mathrm{k} \mathrm{min}^{-1}$. The peak transition temperature was determined to be $188^{\circ} \mathrm{C}$ on heating and $183^{\circ} \mathrm{C}$ on cooling. b) TGA thermogram of $\mathbf{1 / E M I I . ~ c ) ~}$ XRD pattern of 3 at $30^{\circ} \mathrm{C}$. d) POM of image 3 at $30^{\circ} \mathrm{C}$ on cooling. The inset shows the conoscopic image. 


\section{Compound 4}

LC properties of compound 4 were studied by DSC, XRD, TGA and POM. The phase transition temperatures were determined as the onset point of the transition peaks.

a)
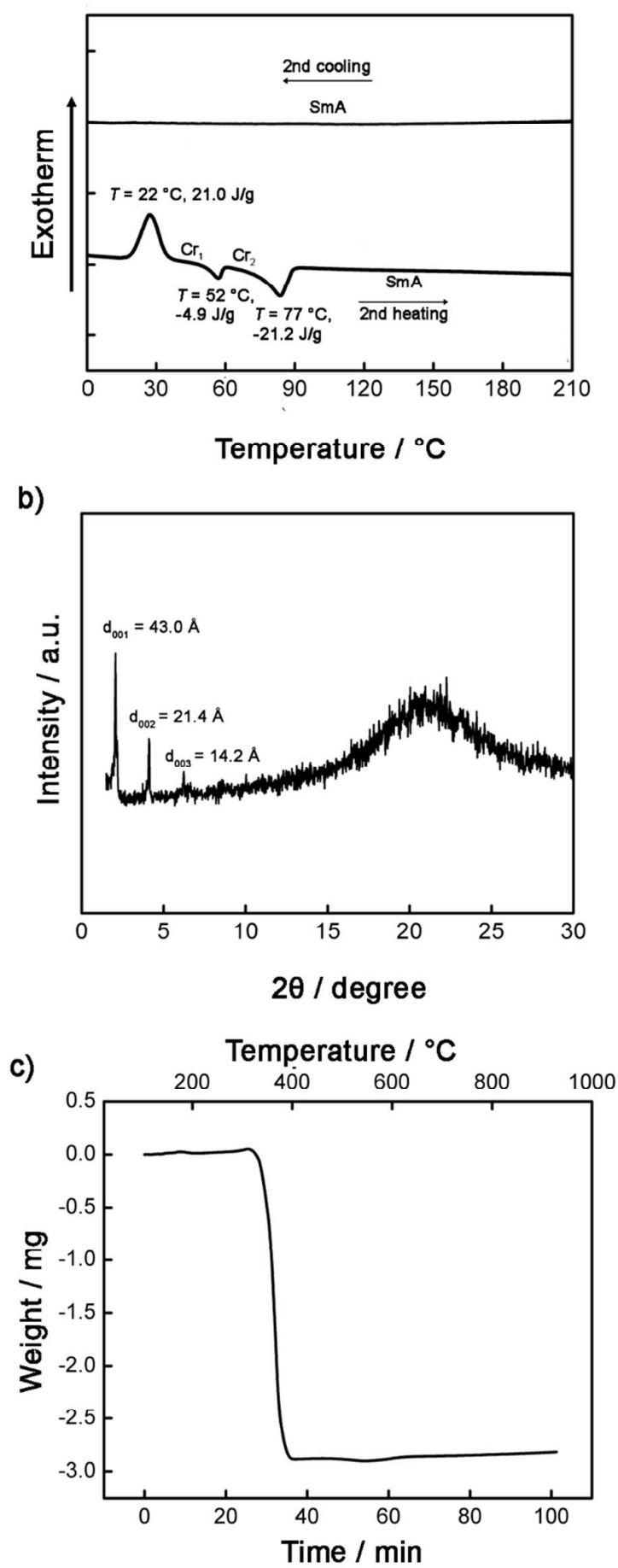

Figure S10. a) DSC thermogram of 4 at a scanning rate of $10 \mathrm{k} \mathrm{min}^{-1}$. b) XRD pattern of 4 at $150{ }^{\circ} \mathrm{C}$. c) TGA thermogram of 4 . 


\section{a)}

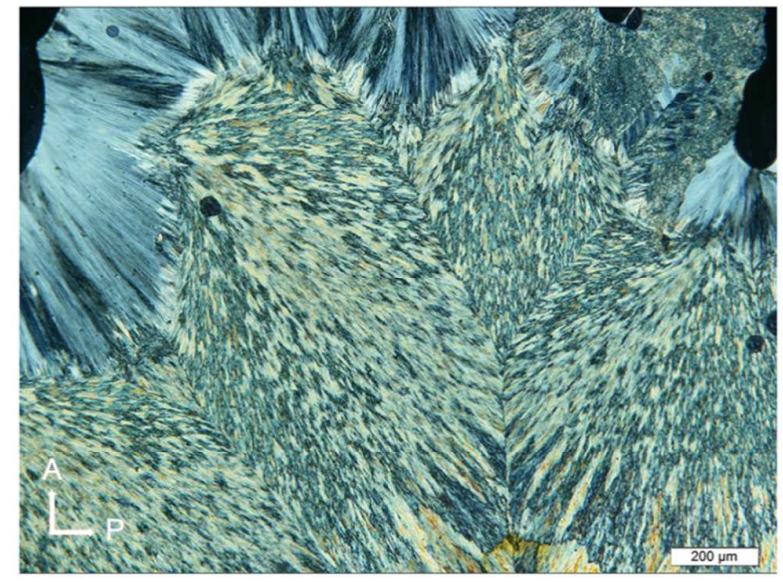

b)

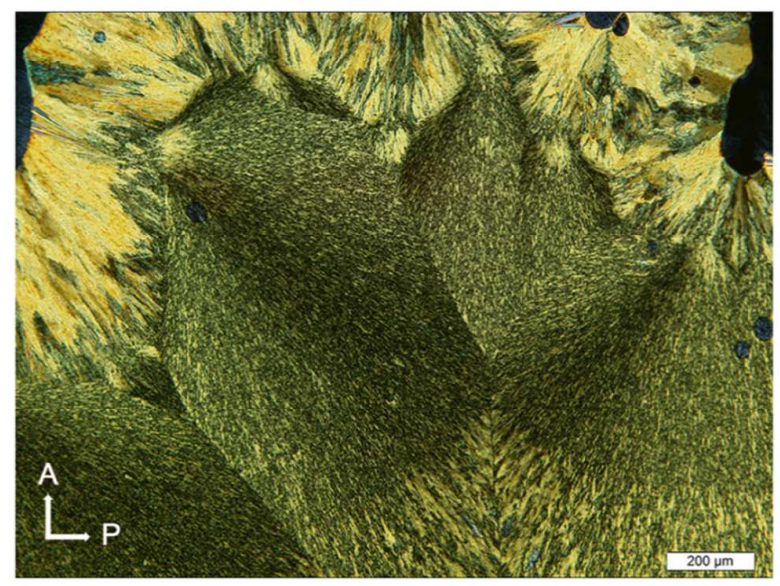

c)

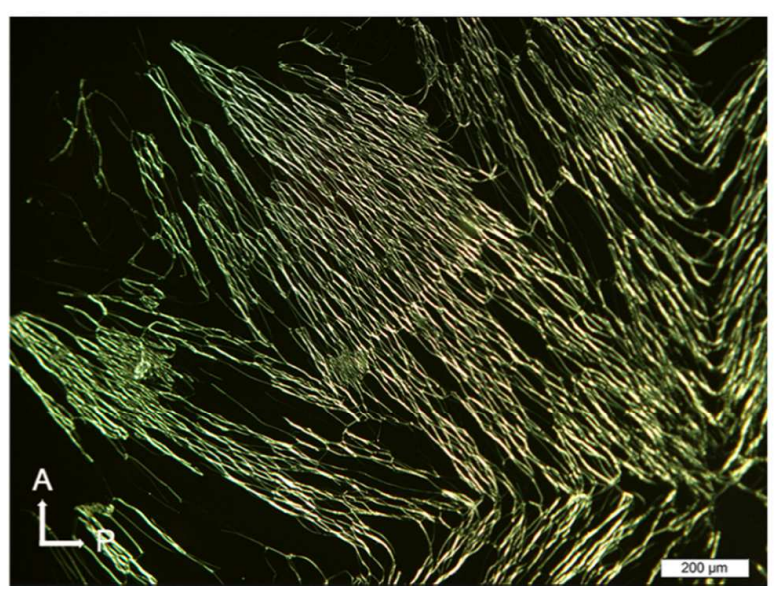

Figure S11 POM images of 4 on heating: a) crystal phase at $45^{\circ} \mathrm{C}$, b) crystal phase at $65^{\circ} \mathrm{C}$, and c) smectic A phase at $150^{\circ} \mathrm{C}$. 


\section{Infrared spectroscopy measurements}

Reflection Fourier Transform Infrared Spectroscopy (FT-IR) measurements of compound 1, EMII and mixture 1/EMII were conducted on the bulk of each sample in air.

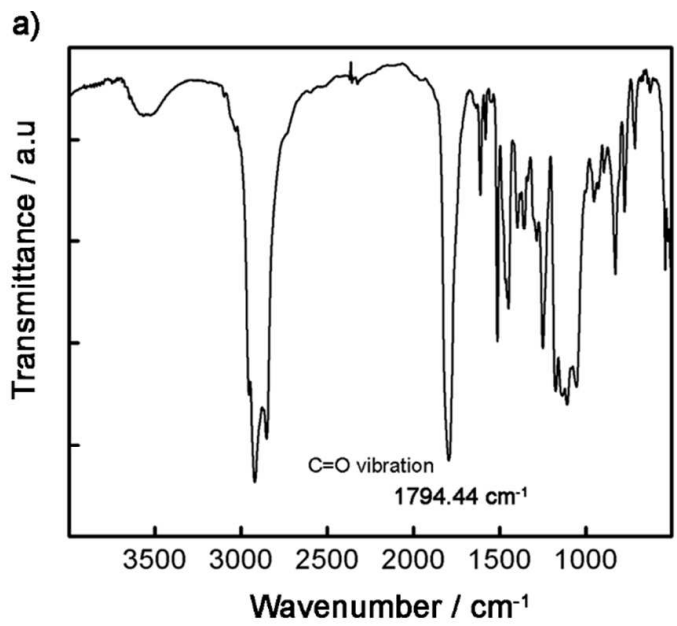

b)

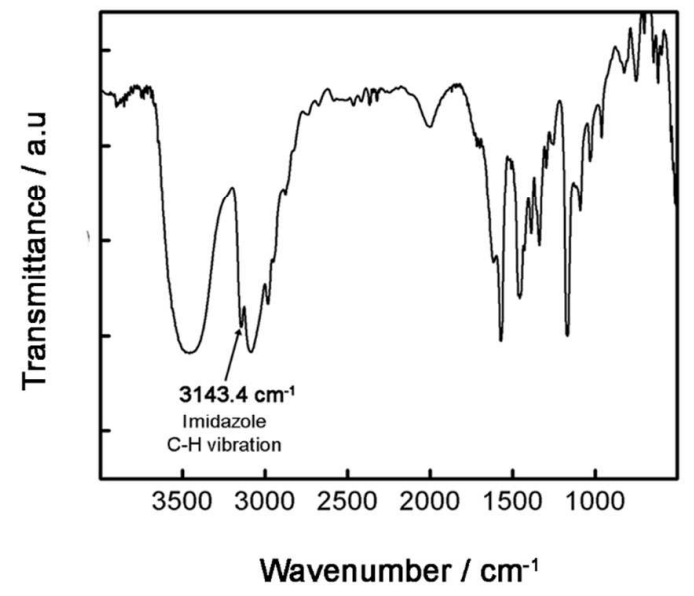

c)

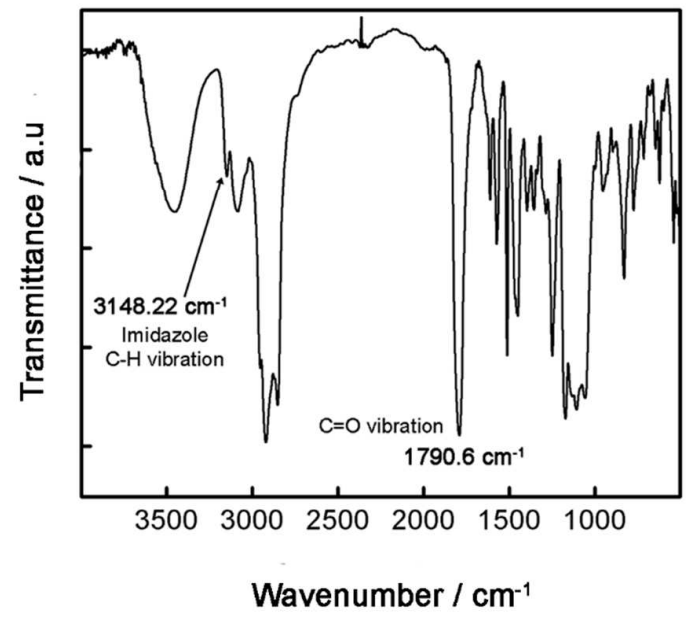

Figure S12. FT-IR spectra of a) compound 1, b) EMII, and c) 1/EMII. 


\section{Characterization of DSSC}

\section{I-V measurements of LC-DSSCs}

The current-voltage (I-V) measurements were conducted under AM $1.5 \mathrm{G}$ illumination $\left(1000 \mathrm{~W} \mathrm{~m}^{-2}\right)$. The devices were kept for 5 minutes at each measurement temperature before the I-V measurement were conducted.

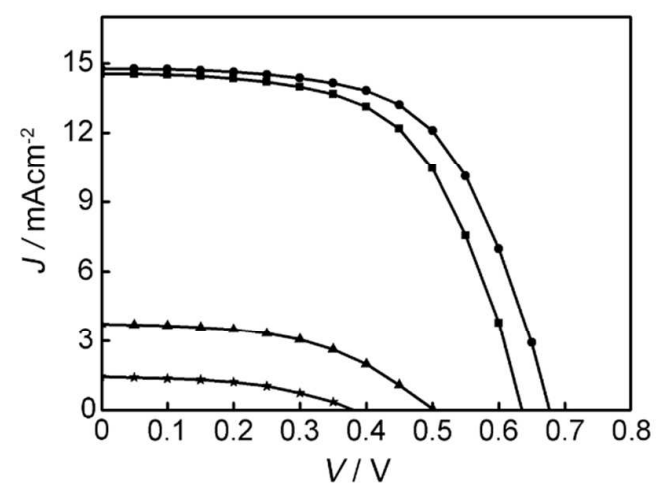

Figure S13. $I-V$ curves of $\mathbf{1 / E M I I - D S S C s}$ at $30{ }^{\circ} \mathrm{C}$ (dots), $60{ }^{\circ} \mathrm{C}$ (squares), $90{ }^{\circ} \mathrm{C}$ (triangles), and 120 ${ }^{\circ} \mathrm{C}$ (stars). The measurements were conducted under AM $1.5 \mathrm{G}$ illumination $\left(1000 \mathrm{~W} \mathrm{~m}^{-2}\right)$.

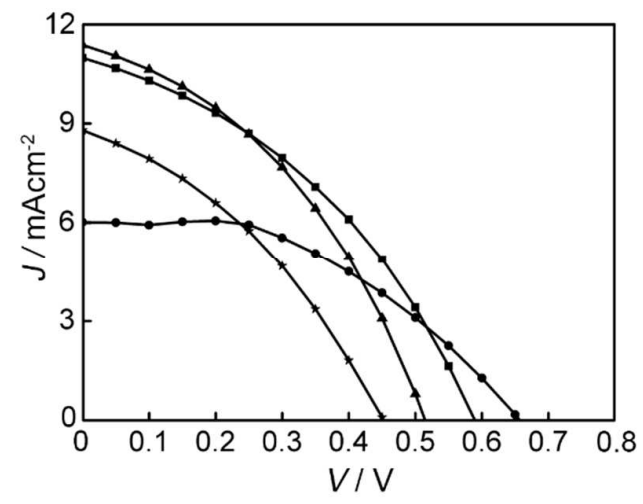

Figure S14. $I-V$ curves of 2-EMII-DSSCs at $30{ }^{\circ} \mathrm{C}$ (dots), $60{ }^{\circ} \mathrm{C}$ (squares), $90{ }^{\circ} \mathrm{C}$ (triangles), and 120 ${ }^{\circ} \mathrm{C}$ (stars). The measurements were conducted under AM $1.5 \mathrm{G}$ illumination $\left(1000 \mathrm{~W} \mathrm{~m}^{-2}\right)$.

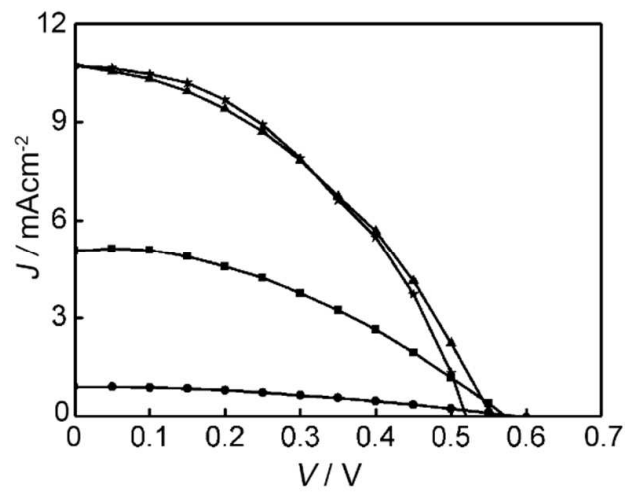

Figure S15. $I-V$ curves of 3-DSSCs at $30{ }^{\circ} \mathrm{C}$ (dots), $60{ }^{\circ} \mathrm{C}$ (squares), $90{ }^{\circ} \mathrm{C}$ (triangles), and $120{ }^{\circ} \mathrm{C}$ (stars). The measurements were conducted under AM $1.5 \mathrm{G}$ illumination $\left(1000 \mathrm{~W} \mathrm{~m}^{-2}\right)$. 


\section{Incident photon-to-current conversion efficiency measurements of LC-DSSCs}

The incident photo-to-current conversion efficiency (IPCE) spectra for the 1/EMII-, 2/EMII-, and 3based DSSCs. The integrated current densities obtained were calculated to be $15.1 \mathrm{~mA} \mathrm{~cm}{ }^{-2}, 11.9 \mathrm{~mA}$ $\mathrm{cm}^{-2}$, and $9.9 \mathrm{~mA} \mathrm{~cm}^{-2}$ for the 1/EMII-, 2/EMII-, and 3-based DSSCs respectively.

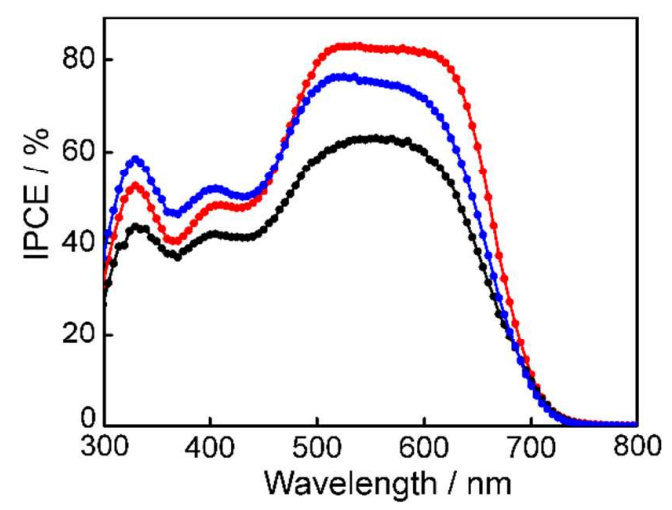

Figure S16. Incident photon-to-current conversion efficiency spectra of 1/EMII-DSSCs (red), 2/EMII-DSSCs (blue), and 3-DSSCs (black).

\section{Electrochemical Impedance Spectroscopy}

The electrochemical impedance spectroscopy (EIS) measurements were conducted at open-circuit conditions under AM 1.5 G illumination $\left(1000 \mathrm{~W} \mathrm{~m}^{-2}\right)$.

a)

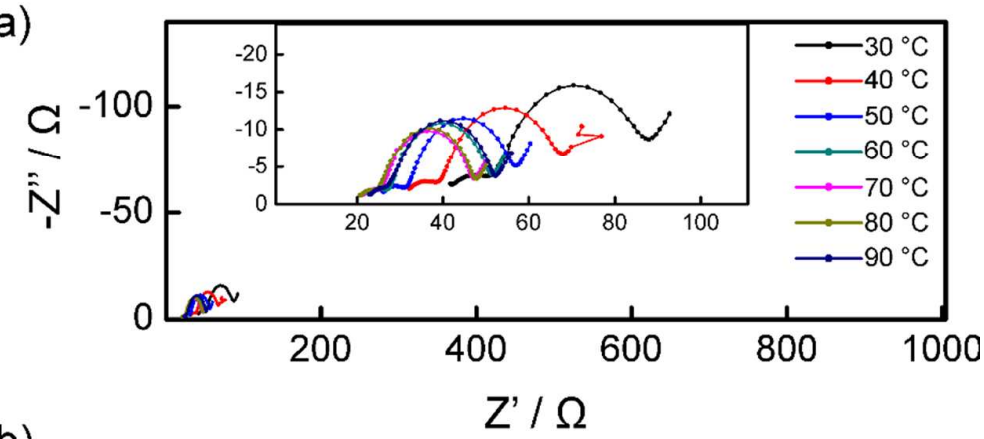

b)

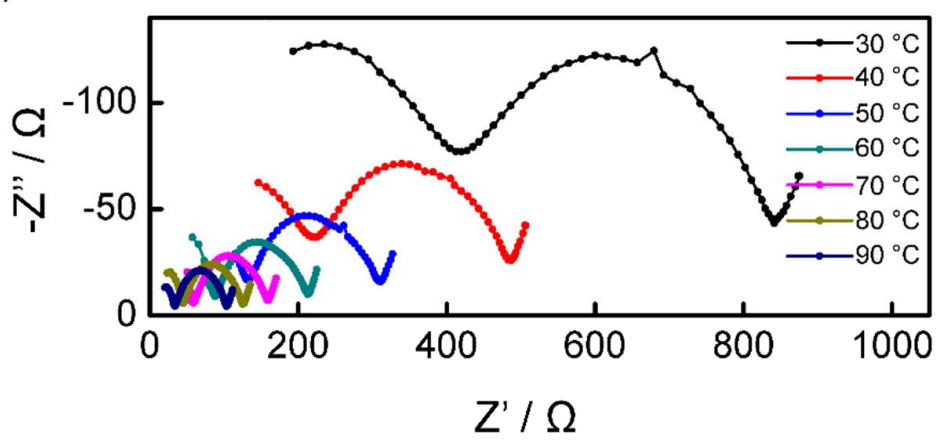

Figure S17. Electrochemical impedance spectra of a) $\mathbf{1 / E M I I}$ and b) $2 / \mathbf{E M I I}$ at different temperatures. The measurements were conducted at open-circuit conditions under AM $1.5 \mathrm{G}$ illumination $\left(1000 \mathrm{~W} \mathrm{~m}^{-2}\right)$. 


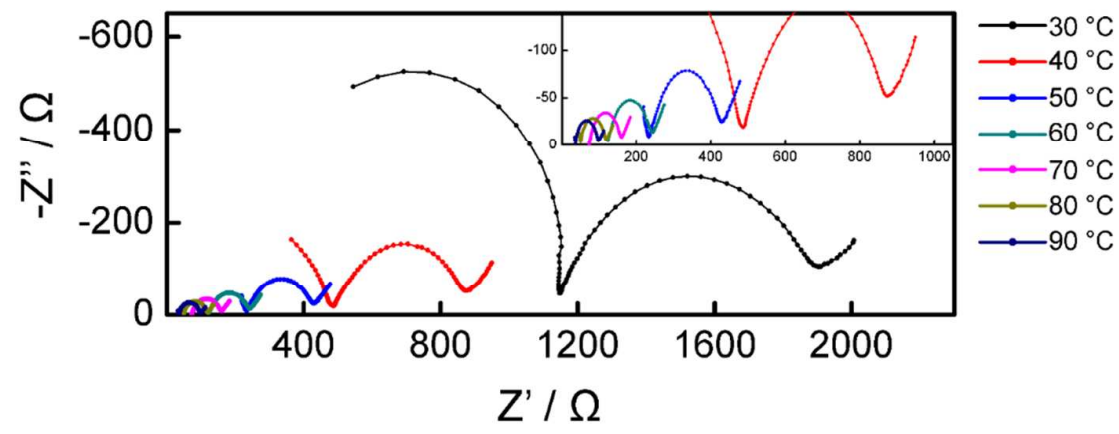

Figure S18. Electrochemical impedance spectra of 3 at different temperatures. The measurements were conducted at open-circuit conditions under AM $1.5 \mathrm{G}$ illumination $\left(1000 \mathrm{~W} \mathrm{~m}^{-2}\right)$.

\section{References}

(S1) Burgy, G.; Tahtouh, T.; Durieu, E.; Foll-Josselin, B.; Limanton, E.; Meijer, L.; Carreaux, F.; Bazureau, F-P. Eur. J. Med. Chem., 2013, 62, 728-737.

(S2) Yamane, S.; Sagara, Y.; Kato, T. Chem. Commun., 2009, 3597-3599.

(S3) Liu, Y.; Wei, W.; Xiong, H. Polymer, 2013, 54, 6572-6570. 